\title{
Interferon-gamma release assays are a better tuberculosis screening test for hemodialysis patients: A study and review of the literature
}

\author{
J Grant $M \mathrm{MCM}^{1}$, J Jastrzebski $M D^{2}$, J Johnston $M D^{3}$, A Stefanovic $M D^{1}$, J Jastrabesky $M D^{2}, K$ Elwood $M D^{3}$, \\ D Roscoe $M D^{1}, R$ Balshaw $P D^{1}$, E Bryce $M D^{1}$
}

\begin{abstract}
J Grant, J Jastrzebski, J Johnston, et al. Interferon-gamma release assays are a better tuberculosis screening test for hemodialysis patients: A study and review of the literature. Can J Infect Dis Med Microbiol 2012;23(3):114-116.

Diagnosing latent tuberculosis (TB) infection (LTBI) in dialysis patients is complicated by poor response to tuberculin skin testing (TST), but the role of interferon-gamma release assays (IGRAs) in the dialysis population remains uncertain. Seventy-nine patients were recruited to compare conventional diagnosis (CD) with the results of two IGRA tests in a dialysis unit. Combining TST, chest $\mathrm{x}$-ray and screening questionnaire results (ie, CD) identified 24 patients as possible LTBI. IGRA testing identified 22 (QuantiFERON Gold IT, Cellestis, USA) and 23 (T-spot.TB, Oxford Immunotec, United Kingdom) LTBI patients. IGRA and CD correlated moderately $(\kappa=0.59)$. IGRA results correlated with history of TB, TB contact and birth in an endemic country. TST was not helpful in identifying LTBI patients in this population. The tendency for IGRAs to correlate with risk factors for TB, active TB infection and history of TB argues for their superiority over TST in dialysis patients. There was no superiority of one IGRA test over another.
\end{abstract}

Key Words: Dialysis; Host; Immunocompromised; Interferon-gamma release assay; Latent tuberculosis infection; Tuberculin skin testing; Tuberculosis

Dialysis patients are 10 to 25 times more likely to develop active tuberculosis (TB) than the general population (1) and are twice as likely to die from their disease (2). Diagnosis can be difficult because this patient population has a myriad of potential causes for symptoms that can mimick TB and are at higher risk for extrapulmonary TB, which is much harder to diagnose. Tuberculin skin testing (TST) is insensitive because dialysis patients have high rates of anergy or may have a false-positive test due to Bacille Calmette-Guérin (BCG) vaccination (2). In vitro assays that measure lymphocyte response to stimulation of ESAT-6 and CFP-10 antigens from Mycobacterium tuberculosis (MTB), called interferon-gamma release assays (IGRAs), appear to be more effective in immunosuppressed populations and are not affected by previous vaccination with BCG (3). The present study, including a literature review, compares the utility of two commercially available IGRAs - QuantiFERON Gold IT (Cellestis, USA) and T-spot.TB (Oxford Immunotec, United Kingdom) - as part of a broader screening program for TB in a hospital-based hemodialysis unit for ambulatory patients.

\section{METHODS}

Recruitment

All patients in the outpatient hemodialysis unit in an urban tertiary care centre were screened for TB risk factors by questionnaire, TST and review of chest x-rays (CXRs) as part of the unit's standard
Les tests de libération d'interféron gamma sont de meilleurs tests de dépistage de la tuberculose chez les patients sous hémodialyse : une étude et une analyse bibliographique

Le diagnostic d'infection tuberculeuse latente (ITBL) chez les patients sous dialyse est compliqué par le peu de réponse au test cutané à la tuberculine (TCT), mais le rôle du test de libération d'interféron gamma (TLIG) au sein de la population sous dialyse demeure incertain. Les auteurs ont recruté 79 patients pour comparer le diagnostic classique (DC) aux résultats de deux TLIG au sein d'une unité de dialyse. L'association du TCT, de la radiographie pulmonaire et des résultats d'un questionnaire de dépistage (c.-à-d. le DC) a permis de dépister 24 patients comme pouvant être atteints d'une ITBL. Le TLIG a permis de dépister 22 (QuantiFERON Gold IT, Cellestis, ÉtatsUnis) et 23 (T-spot.TB, Oxford Immunotec, Royaume-Uni) patients atteints d'une ITBL. Le TLIG et le DC avaient une corrélation modérée $(\kappa=0,59)$. Les résultats du TLIG étaient corrélés avec les antécédents de tuberculose (TB), les contacts atteints de TB et la naissance dans un pays endémique. Le TCT ne contribuait pas à dépister les patients atteints d'une ITBL au sein de cette population. La tendance des TLIG à être corrélés avec les facteurs de risque de TB, une infection active par la TB et les antécédents de TB laisse supposer leur supériorité par rapport au TCT chez les patients sous dialyse. Aucun type de TLIG n'était supérieur aux autres.

screening following an inadvertent TB exposure. All chronic dialysis patients dialyzed on Monday through Thursday until 15:00 (to allow the laboratory to manage samples during regular hours) were considered eligible for the study, except for patients who were pregnant, acutely ill (including anybody who was hospitalized at the time of study), younger than 18 years of age or unable to consent. The present study was approved by the institutional ethics board. Study participants gave informed consent for both QuantiFERON Gold IT and T-Spot.TB testing. Acutely ill patients requiring urgent dialysis were excluded from the study and any patient suspected of having active TB was excluded from the study and referred to a TB clinic for further evaluation and treatment.

\section{Power calculation}

The number of study subjects necessary for $80 \%$ power to detect a $20 \%$ difference with a one-sided test at $\alpha=0.05$ was calculated to be 42 by assuming a proportion of positive test results of $13 \%$ using the TST and $36 \%$ using IGRA based on data from another Canadian centre (4).

\section{Questionnaires}

A questionnaire was modified from the California Tuberculosis Controller's Association guidelines for TB screening in renal failure populations (5). The questionnaire was administered by dialysis unit nursing staff and translated as needed by dialysis staff or patient families (Appendix 1, go to www.pulsus.com).

${ }^{1}$ Division of Medical Microbiology, Department of Pathology and Laboratory Medicine; ${ }^{2}$ Division of Nephrology, Department of Internal Medicine, Vancouver General Hospital; ${ }^{3}$ Tuberculosis Control, British Columbia Centres for Disease Control, Vancouver, British Columbia

Correspondence: Dr J Grant, Jim Pattison Pavilion North 1110 Microbiology, Vancouver General Hospital, 855 West 12th Avenue, Vancouver,

British Columbia V5Z 2A1. Telephone 604-875-4111 ext 69503, e-mail jennifer.grant@vch.ca 
TABLE 1

\section{Patient characteristics}

\begin{tabular}{lc}
\hline Age, years, mean & 73.4 \\
Duration of dialysis, years, mean & 3.54 \\
Diabetic & 32 \\
Bacille Calmette-Guérin vaccinated & 14 \\
Country of origin & \\
Canada & 27 \\
China & 31 \\
Philippines & 7 \\
Hong Kong & 5 \\
Italy & 5 \\
Vietnam & 5 \\
Other & 20 \\
\hline
\end{tabular}

Data presented as \% unless otherwise indicated

\section{TST}

Single-step skin testing was performed using five tuberculin units intradermally and read at $48 \mathrm{~h}$ by the same, experienced, occupational health nurse.

\section{CXR}

Routine CXRs performed for clinical reasons were used to screen for evidence of active or latent TB. Patients who had multiple CXRs had all available films evaluated. Patients who had not had a CXR within the previous year had a specific TB screening CXR performed.

\section{Physician panel}

The physician panel was composed of five physicians specialized in respiratory medicine $(n=2)$, nephrology $(n=1)$ or infectious diseases $(n=2)$. Panel members were presented with the results of the TST, questionnaire and CXR results, and asked to categorize patients as having a latent TB infection (LTBI) or not. Patients in whom four of five physicians gave the same categorization were counted according to the majority opinion. Patients with two or more discrepant results were reviewed by the entire panel to achieve consensus categorization of at least four of five physicians.

\section{IGRAs}

Blood was collected simultaneously for QuantiFERON Gold IT and T-Spot.TB assays, according to manufacturer's directions, immediately before dialysis. Blood was transported within $1 \mathrm{~h}$ to an onsite laboratory that incubated the QuantiFERON Gold IT and processed the T-Spot.TB within $2 \mathrm{~h}$ of receipt.

\section{Literature search}

MEDLINE was queried for the following search terms: "interferon gamma" or "interferon gamma release assay", "renal dialysis" or "dialysis", "QuantiFERON", "elispot" and "T-spot TB". Articles identified under any of these search terms were examined and included if they involved studies comparing IGRA testing with conventional testing in dialysis patients. In addition, the references of all identified articles were examined to identify additional studies not identified in the original search.

\section{Patient population}

\section{RESULTS}

Of a potential 182 patients, 81 were deemed eligible (based on time of dialysis) and 80 were recruited. One patient had insufficient data; results are based on the remaining 79 patients. Demographics are presented in Table 1. Four patients were known to have had active TB in the past and three were known contacts of active TB patients. One patient was being treated for extrapulmonary $\mathrm{TB}$ at the time of questionnaire administration and was unaware that he was being treated for TB.

\section{TST}

Of the 79 study subjects, two patients did not have a TST placed because they were being treated for active or latent TB. Two patients

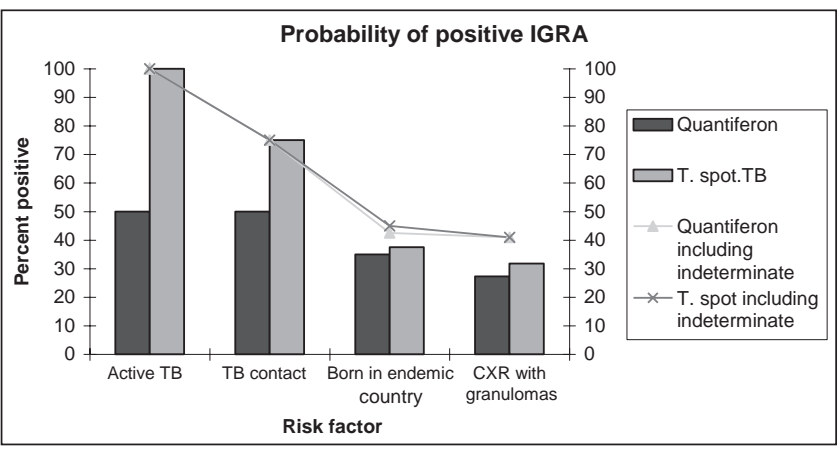

Figure 1) Comparison of interferon-gamma release assay (IGRA) results according to known risk factors for tuberculosis (TB). CXR Chest x-ray

(2.6\%) had indurations greater than $10 \mathrm{~mm}$ and one additional patient had an induration of between $5 \mathrm{~mm}$ and $10 \mathrm{~mm}$.

\section{Physician panel}

The physician panel agreed completely (five of five) on 66 (83\%) cases, agreed in majority (four of five ) in 10 (13\%) cases, and three (4\%) cases required review. Twenty-four $(30 \%)$ patients were identified as having a LTBI, and 55 were determined to be noninfected.

\section{IGRA results}

T-Spot.TB yielded $22(28 \%)$ positive, 50 negative and seven indeterminate results. QuantiFERON Gold IT yielded 22 (28\%) positive, 51 negative and six indeterminate results. IGRAs agreed with one another $78 \%$ of the time; if indeterminate results were discarded, agreement was $96 \%(\kappa=0.95)$. Of the indeterminate results, none were concordant (ie, no patient had two indeterminate results). All TST-positive patients were positive by IGRA, and one TST-positive patient had an indeterminate result to QuantiFERON Gold IT, but was positive by T-spot.TB. The agreement between IGRA and TST was poor $(\kappa=0.04)$.

\section{IGRA and physician panel}

IGRAs had moderate correlation with the physician panel $(\kappa=0.59)$. Of the 28 (35\%) IGRA and physician panel discordant patients, there were 13 IGRA-negative patients that the physician panel believed were likely to have LTBI; seven had CXR findings identified by a radiologist as being consistent with granulomatous disease. Of the 15 patients whom the physician panel believed had no findings consistent with TB, but were IGRA positive, five had granulomas identified on imaging of body sites other than the chest and one had been diagnosed with TB of the bone during the study but failed to mention it on his questionnaire.

\section{Risk factor analysis}

Known history of active TB was associated with a $100 \%$ IGRA positivity by T-spot.TB (Figure 1) and 50\% positivity by QuantiFERON Gold IT. It should be noted that the remaining $50 \%$ were indeterminate by QuantiFERON Gold IT. The OR for positive QuantiFERON Gold IT with a history of TB was 1.79 while T-spot.TB had a $3.78 \mathrm{OR}$ for patients with a history of TB. The likelihood of having a positive IGRA with known TB contact was $50 \%$ and $75 \%$ for QuantiFERON Gold IT and T-spot.TB, respectively.

\section{Literature review}

The search identified nine studies (4,6-13) directly comparing IGRAs with conventional LTBI diagnostic methods in dialysis patients. Two studies examined only T-Spot.TB, two studies only QuantiFERON (all versions) and four evaluated both QuantiFERON (all versions) and T-Spot.TB. The agreement between traditional methods and IGRA tests, where available, were $\kappa=0.27$ to 0.37 . IGRAs tended to correlate more strongly with active TB, exposure to TB or risk factors for TB. 


\section{DISCUSSION}

Diagnosing LTBI is difficult and lacks a gold standard; consequently, the evaluation of new technology requires the use of surrogate markers. Our data, and those of other groups, show that IGRAs strongly correlate with known risk factors for disease including history of disease, birth in an endemic area and known exposure to a person with active disease. Specifically, there is strong correlation between active disease, history of active disease and TB exposure. While this is not a perfect measure, it suggests that IGRAs accurately reflect what is known about TB epidemiology.

TST testing did not contribute substantially to the value of the screening program in the present study. IGRAs are more frequently positive in dialysis populations than TST and are more convenient. While a negative IGRA is associated with low risk of progression to active TB (14), there is still uncertainty about the precise risk of progression to disease with a positive IGRA. However, two recent studies suggest that the rate of progression is between $8 \%$ to $15 \%$ for IGRApositive patients compared with $2 \%$ to $3 \%$ for TST-positive patients $(15,16)$. Therefore, IGRA results should be considered as valuable supplemental information to conventional diagnosis, such as screening questionnaires for identification of risk factors, history and physical examination, and CXRs.

\section{REFERENCES}

1. ATS/CDC Statement Committee on Latent Tuberculosis: Infection targeted tuberculin testing and treatment of latent tuberculosis infection. American Thoracic Society. MMWR Recomm Rep 2000;49:1-51.

2. Ahmed AT, Karter AJ. Tuberculosis in California dialysis patients. Int J Tuberc Lung Dis 2004;8:341-5.

3. Mori T. Usefulness of interferon-gamma release assays for diagnosing TB infection and problems with these assays. J Infect Chemother 2009;15:143-55.

4. Passalent L, Khan K, Richardson R, Wang J, Dedier H, Gardam M. Detecting latent tuberculosis infection in hemodialysis patients: A head-to-head comparison of the T-SPOT.TB test, tuberculin skin test, and an expert physician panel. Clin J Am Soc Nephrol 2007;2:68-73.

5. California Tuberculosis Controllers Association: Guidelines for tuberculosis screening and treatment of patients with chronic kidney disease. <www.ctca.org/guidelines/New_Renal_Dialysis_ Guidelines_02_22_08.pdf> (Accessed July 10, 2008).

6. Lee SS, Chou KJ, Su IJ, et al. High prevalence of latent tuberculosis infection in patients in end-stage renal disease on hemodialysis: Comparison of QuantiFERON-TB GOLD, ELISPOT, and tuberculin skin test. Infection 2009;37:96-102.

7. Inoue $\mathrm{T}, \mathrm{Nakamura} T$, Katsuma A, et al. The value of QuantiFERON TB-Gold in the diagnosis of tuberculosis among dialysis patients. Nephrol Dial Transplant 2009;24:2252-7.

8. Triverio PA, Bridevaux PO, Roux-Lombard P, et al. Interferongamma release assays versus tuberculin skin testing for detection of latent tuberculosis in chronic haemodialysis patients. Nephrol Dial Transplant 2009;24:1952-6.
Interpretation of existing studies depends on pretest probability; the proportions of positive IGRA tests correlate, but not directly, with the rate of TB infection in the general population. The presence of immigrants from endemic countries explains some of this discrepancy, and must be considered when implementing a screening program. The present study included almost $80 \%$ of participants who were either foreign born $(70 \%)$, or who had other known risk factors for TB (6\%). Therefore, greater sensitivity is of critical importance.

A recent meta-analysis found a very slight increased sensitivity for T-spot.TB over QuantiFERON, but better specificity with QuantiFERON (20). Sample sizes in that study were too small to draw conclusions as to the sensitivity and specificity of each test in the dialysis population; however, our data suggest that the choice of test may be more a matter of local preference. There are few head-tohead comparisons of the two available IGRAs in dialysis.

Based on the data generated in the present study, IGRA testing has been endorsed as part of a comprehensive screening program for LTBI. IGRAs show a higher sensitivity in dialysis populations than TST and are more convenient.

ACKOWLEDGEMENTS: The authors gratefully thank the Provincial Renal Agency of British Collumbia for providing the resources necessary to perform this study.

9. Winthrop KL, Nyendak M, Calvet $\mathrm{H}$, et al. Interferon-gamma release assays for diagnosing Mycobacterium tuberculosis infection in renal dialysis patients. Clin J Am Soc Nephrol 2008;3:1357-63.

10. Chung WK, Zheng ZL, Sung JY, Kim et al. Validity of interferongamma-release assays for the diagnosis of latent tuberculosis in haemodialysis patients. Clin Microbiol Infect 2010;16:960-5.

11. Kim SH, Lee SO, Park IA, et al. Diagnostic usefulness of a T cellbased assay for latent tuberculosis infection in kidney transplant candidates before transplantation. Transpl Infect Dis 2010;12:113-9.

12. Hoffmann M, Tsinalis D, Vernazza P, Fierz W, Binet I. Assessment of an interferon-gamma release assay for the diagnosis of latent tuberculosis infection in haemodialysis patient. Swiss Med Wkly 2010;140:286-92.

13. Lai CC, Tan CK, Liao CH, Chou CH, Huang YT, Hsueh PR. Diagnosis of pulmonary tuberculosis among dialysis patients by enzyme-linked immunospot assay for interferon-gamma. Nephrol Dial Transplant 2009;24:2605-6.

14. Mazurek GH, Villarino ME, CDC. Guidelines for using the QuantiFERON-TB test for diagnosing latent Mycobacterium tuberculosis infection. Centers for Disease Control and Prevention. MMWR Recomm Rep 2003;52:15-18.

15. Diel R, Goletti D, Ferrara G, et al. Interferon-gamma release assays for the diagnosis of latent Mycobacterium tuberculosis infection: A systematic review and meta-analysis. Eur Respir J 2011;37:88-99.

16. Diel R, Loddenkemper R, Nienhaus A. Evidence-based comparison of commercial interferon-gamma release assays for detecting active TB: A metaanalysis. Chest 2010;137:952-68. 


\section{TB Screening Questionnaire}

\section{Page: 1 of 2}

\begin{tabular}{|c|c|c|c|}
\hline \multicolumn{3}{|c|}{ Patient: TEST, PATIENT DIALYSIS } & Male \\
\hline \multicolumn{2}{|l|}{ PHN: } & \multicolumn{2}{|c|}{ DOB: $01-J A N-49$} \\
\hline \multirow[t]{3}{*}{ Address: } & \multicolumn{3}{|c|}{4435 ST GEORGE STREET } \\
\hline & \multicolumn{3}{|l|}{ VANCOUVER } \\
\hline & Home phone \# : & $(60$ & $879-8148$ \\
\hline
\end{tabular}

INSTRUCTIONS: Please fill-in or circle the appropriate answer to the following list of questions:

\section{GENERAL}

1.1. Country of birth ( If the answer is CANADA, go to 1.3 ) :

1.2. Year immigrated to Canada:

1.3. Ethnicity (circle one):

\begin{tabular}{|l|l|}
\hline 1 & Asian Filipino \\
\hline 4 & Black \\
\hline 7 & North American Indian \\
\hline
\end{tabular}

\begin{tabular}{|l|l|}
\hline 2 & Asian Indian \\
\hline 5 & Caucasian \\
\hline 8 & Other \\
\hline
\end{tabular}

3 Asian Oriental

6 Inuit

9 Unknown

1.4. If Other Ethnicity, Specify:

1.5. Year started on dialysis:

1.6. Are you Diabetic? If the answer is No, go to 1.8 .

1.7. Are you on Insulin?

1.8. Have you ever had active TB? If the answer is No, go to 1.10 .

1.9. If you had TB, was it treated?

1.10. Have you lived with or been in close contact with someone who had active TB?

\section{SYMPTOMS}

Have you experienced any of the following symptoms within the past year?

\begin{tabular}{|l|c||c||c|}
\hline 2.1. Cough (with or without phlegm) for $>3$ weeks: & Yes & No & Unk \\
\hline 2.2. Coughing up blood: & Yes & No & Unk \\
\hline 2.3. Chest pain: & Yes & No & Unk \\
\hline 2.4. Shortness of breath/difficulties breathing: & Yes & No & Unk \\
\hline 2.5. Unexplained fever: & Yes & No & Unk \\
\hline 2.6. Unexplained excessive night sweats: & Yes & No & Unk \\
\hline 2.7. Unexplained weight loss: & Yes & No & Unk \\
\hline 2.8. Unexplained excessive fatigue: & Yes & No & Unk \\
\hline
\end{tabular}




\section{TB Screening Questionnaire}

Page: 2 of 2

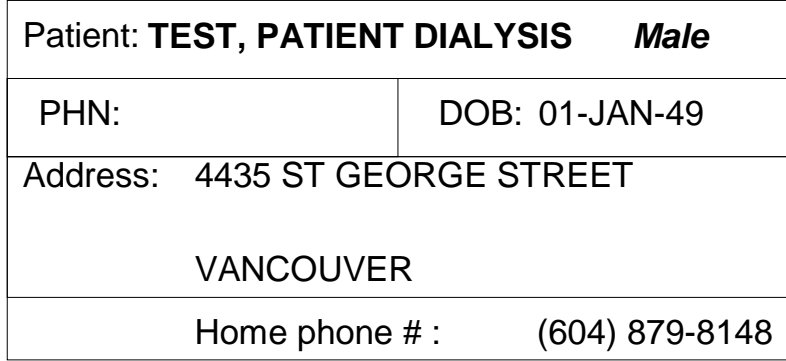

INSTRUCTIONS: Please fill-in or circle the appropriate answer to the following list of questions:

\section{TB TESTING}

\begin{tabular}{|l|r||r||r|}
\hline 3.1. Have you ever had a TB skin test? If the answer is No, go to 3.4. & \multicolumn{1}{|c||}{ Yes } & No & Unk \\
\hline 3.2. What was the result? If the answer is No, go to 3.4. & $>=10 \mathrm{~mm}$ & $<10 \mathrm{~mm}$ & Unk \\
\hline 3.3. Do you have a written proof of TB skin test: & Yes & No & Unk \\
\hline 3.4. Have you ever received BCG vaccination? & Yes & No & Unk \\
\hline 3.5. Have you ever had an abnormal chest x-ray? & Yes & No & Unk \\
\hline
\end{tabular}

\section{CONSIDERING THE LIST OF COUNTRIES/CONTINENTS BELOW:}
a) Africa (any country)
b) Asia (China, Mongolia, Vietnam, Korea, Indonesia, India, Pakistan, Bangladesh, India)
c) Europe (any country of former Soviet Union)
d) Latin America: (Any country)
e) Carribean Islands (Jamaica, Dominican Republic, Haiti, Cuba, Trinidad)
f) Pacific Islands including the Philippines but excluding Hawaii

\begin{tabular}{|c|c|c|c|}
\hline 4.1 Were you born in any of these places? & Yes & No & Unk \\
\hline 4.2 Have you ever stayed/visited in one of these places for $>$ one moth? & Yes & No & Unk \\
\hline $\begin{array}{l}\text { 4.3 Have you ever lived or been in close contact with someone who lived in any of these } \\
\text { places for > one month? }\end{array}$ & Yes & No & Unk \\
\hline
\end{tabular}

\section{COMMENTS}




\section{TB Screening Questionnaire}

\section{Page: 1 of 2}

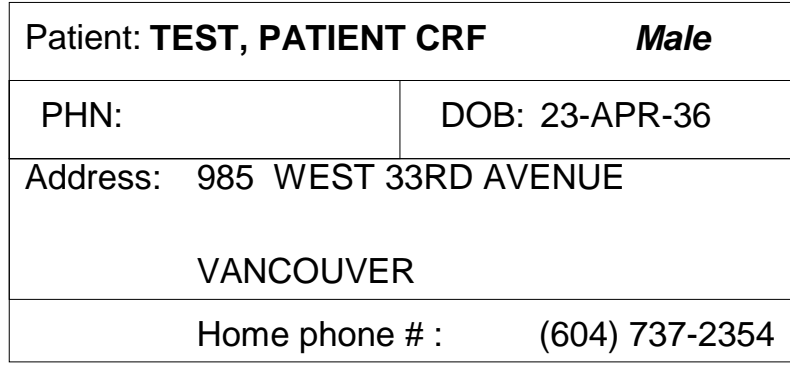

INSTRUCTIONS: Please fill-in or circle the appropriate answer to the following list of questions:

\section{GENERAL}

1.1. Country of birth ( If the answer is CANADA, go to 1.3 ) :

1.2. Year immigrated to Canada:

1.3. Ethnicity (circle one):

\begin{tabular}{|l|l|}
\hline 1 & Asian Filipino \\
\hline 4 & Black \\
\hline 7 & North American Indian \\
\hline
\end{tabular}

\begin{tabular}{|l|l|}
\hline 2 & Asian Indian \\
\hline 5 & Caucasian \\
\hline 8 & Other \\
\hline
\end{tabular}

3 Asian Oriental

6 Inuit

9 Unknown

1.4. If Other Ethnicity, Specify:

1.5. Year started on dialysis:

1.6. Are you Diabetic? If the answer is No, go to 1.8 .

1.7. Are you on Insulin?

1.8. Have you ever had active TB? If the answer is No, go to 1.10 .

1.9. If you had TB, was it treated?

1.10. Have you lived with or been in close contact with someone who had active TB?

\section{SYMPTOMS}

Have you experienced any of the following symptoms within the past year?

\begin{tabular}{|l|c||c||c|}
\hline 2.1. Cough (with or without phlegm) for $>3$ weeks: & Yes & No & Unk \\
\hline 2.2. Coughing up blood: & Yes & No & Unk \\
\hline 2.3. Chest pain: & Yes & No & Unk \\
\hline 2.4. Shortness of breath/difficulties breathing: & Yes & No & Unk \\
\hline 2.5. Unexplained fever: & Yes & No & Unk \\
\hline 2.6. Unexplained excessive night sweats: & Yes & No & Unk \\
\hline 2.7. Unexplained weight loss: & Yes & No & Unk \\
\hline 2.8. Unexplained excessive fatigue: & Yes & No & Unk \\
\hline
\end{tabular}




\section{TB Screening Questionnaire}

Page: 2 of 2

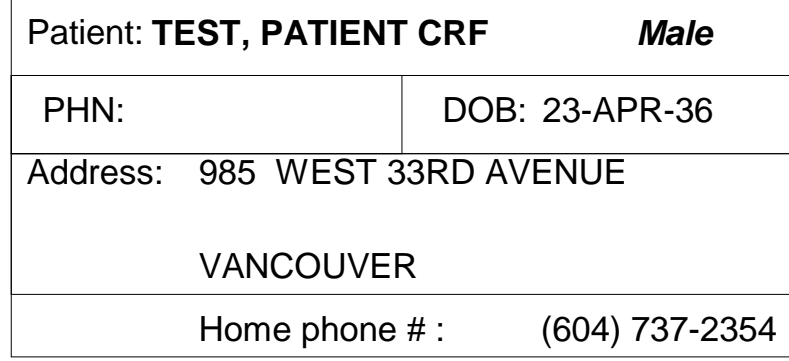

INSTRUCTIONS: Please fill-in or circle the appropriate answer to the following list of questions:

\section{TB TESTING}

\begin{tabular}{|c|c|c|c|}
\hline 3.1. Have you ever had a TB skin test? If the answer is No, go to 3.4. & Yes & No & Unk \\
\hline 3.2. What was the result? If the answer is No, go to 3.4 . & $>=10 \mathrm{~mm}$ & $<10 \mathrm{~mm}$ & Unk \\
\hline 3.3. Do you have a written proof of TB skin test: & Yes & No & Unk \\
\hline 3.4. Have you ever received BCG vaccination? & Yes & No & Unk \\
\hline 3.5. Have you ever had an abnormal chest $\mathrm{x}$-ray? & Yes & No & Unk \\
\hline
\end{tabular}

\section{CONSIDERING THE LIST OF COUNTRIES/CONTINENTS BELOW:}
a) Africa (any country)
b) Asia (China, Mongolia, Vietnam, Korea, Indonesia, India, Pakistan, Bangladesh, India)
c) Europe (any country of former Soviet Union)
d) Latin America: (Any country)
e) Carribean Islands (Jamaica, Dominican Republic, Haiti, Cuba, Trinidad)
f) Pacific Islands including the Philippines but excluding Hawaii

\begin{tabular}{|c|c|c|c|}
\hline 4.1 Were you born in any of these places? & Yes & No & Unk \\
\hline 4.2 Have you ever stayed/visited in one of these places for $>$ one moth? & Yes & No & Unk \\
\hline $\begin{array}{l}\text { 4.3 Have you ever lived or been in close contact with someone who lived in any of these } \\
\text { places for > one month? }\end{array}$ & Yes & No & Unk \\
\hline
\end{tabular}

\section{COMMENTS}




\section{TB Screening Questionnaire}

Page: 1 of 2

\begin{tabular}{|c|c|c|}
\hline \multicolumn{2}{|c|}{ Patient: TEST, PT TBSURVEY } & Male \\
\hline PHN: 9069483047 & $\mathrm{DOB}$ & 09-FEB-39 \\
\hline \multicolumn{3}{|c|}{$\begin{array}{ll}\text { Address: } & \text { 225-310 ALEXANDER STREET } \\
& \text { DVA BUILDING: VETS MANOR } \\
& \text { VANCOUVER }\end{array}$} \\
\hline Home ph & & (604) $761-2162$ \\
\hline
\end{tabular}

INSTRUCTIONS: Please fill-in or circle the appropriate answer to the following list of questions:

\section{GENERAL}

1.1. Country of birth ( If the answer is CANADA, go to 1.3 ) :

1.2. Year immigrated to Canada:

1.3. Ethnicity (circle one):

\begin{tabular}{|l|l|}
\hline 1 & Asian Filipino \\
\hline 4 & Black \\
\hline 7 & North American Indian \\
\hline
\end{tabular}

\begin{tabular}{|ll|}
\hline 2 & Asian Indian \\
\hline 5 & Caucasian \\
\hline 8 & Other \\
\hline
\end{tabular}

\begin{tabular}{|l|l|}
\hline 3 & Asian Oriental \\
\hline 6 & Inuit \\
\hline 9 & Unknown \\
\hline
\end{tabular}

1.4. If Other Ethnicity, Specify:

1.5. Year started on dialysis:

\begin{tabular}{|l|c|c|c|}
\hline 1.6. Are you Diabetic? If the answer is No, go to 1.8. & Yes & No & Unk \\
\hline 1.7. Are you on Insulin? & Yes & No & Unk \\
\hline 1.8. Have you ever had active TB? If the answer is No, go to 1.10. & Yes & No & Unk \\
\hline 1.9. If you had TB, was it treated? & Yes & No & Unk \\
\cline { 1 - 2 } 1.10. Have you lived with or been in close contact with someone who had active TB? & Yes & No & Unk \\
\hline
\end{tabular}

\section{SYMPTOMS}

Have you experienced any of the following symptoms within the past year?

\begin{tabular}{|l|c||c||c|}
\hline 2.1. Cough (with or without phlegm) for $>3$ weeks: & Yes & No & Unk \\
\hline 2.2. Coughing up blood: & Yes & No & Unk \\
\hline 2.3. Chest pain: & Yes & No & Unk \\
\hline 2.4. Shortness of breath/difficulties breathing: & Yes & No & Unk \\
\hline 2.5. Unexplained fever: & Yes & No & Unk \\
\hline 2.6. Unexplained excessive night sweats: & Yes & No & Unk \\
\hline 2.7. Unexplained weight loss: & Yes & No & Unk \\
\hline 2.8. Unexplained excessive fatigue: & Yes & No & Unk \\
\hline
\end{tabular}




\section{TB Screening Questionnaire}

Page: 2 of 2

\begin{tabular}{|c|c|c|}
\hline \multicolumn{2}{|c|}{ Patient: TEST, PT TBSURVEY } & Male \\
\hline PHN: 9069483047 & $\mathrm{DOB}$ & 09-FEB-39 \\
\hline \multicolumn{3}{|c|}{$\begin{array}{ll}\text { Address: } & \text { 225-310 ALEXANDER STREET } \\
& \text { DVA BUILDING: VETS MANOR } \\
& \text { VANCOUVER }\end{array}$} \\
\hline Home ph & & (604) $761-2162$ \\
\hline
\end{tabular}

INSTRUCTIONS: Please fill-in or circle the appropriate answer to the following list of questions:

\section{TB TESTING}

\begin{tabular}{|l|r||r||r|}
\hline 3.1. Have you ever had a TB skin test? If the answer is No, go to 3.4. & \multicolumn{1}{|c||}{ Yes } & No & Unk \\
\hline 3.2. What was the result? If the answer is No, go to 3.4. & $>=10 \mathrm{~mm}$ & $<10 \mathrm{~mm}$ & Unk \\
\hline 3.3. Do you have a written proof of TB skin test: & Yes & No & Unk \\
\hline 3.4. Have you ever received BCG vaccination? & Yes & No & Unk \\
\hline 3.5. Have you ever had an abnormal chest x-ray? & Yes & No & Unk \\
\hline
\end{tabular}

\section{CONSIDERING THE LIST OF COUNTRIES/CONTINENTS BELOW:}
a) Africa (any country)
b) Asia (China, Mongolia, Vietnam, Korea, Indonesia, India, Pakistan, Bangladesh, India)
c) Europe (any country of former Soviet Union)
d) Latin America: (Any country)
e) Carribean Islands (Jamaica, Dominican Republic, Haiti, Cuba, Trinidad)
f) Pacific Islands including the Philippines but excluding Hawaii

\begin{tabular}{|c|c|c|c|}
\hline 4.1 Were you born in any of these places? & Yes & No & Unk \\
\hline 4.2 Have you ever stayed/visited in one of these places for $>$ one moth? & Yes & No & Unk \\
\hline $\begin{array}{l}\text { 4.3 Have you ever lived or been in close contact with someone who lived in any of these } \\
\text { places for > one month? }\end{array}$ & Yes & No & Unk \\
\hline
\end{tabular}

\section{COMMENTS}




\section{TB Screening Questionnaire}

\section{Page: 1 of 2}

\begin{tabular}{|c|c|}
\hline Patient: & Male \\
\hline PHN: & DOB: 31-DEC-99 \\
\hline Address & \\
\hline & \\
\hline & \\
\hline
\end{tabular}

INSTRUCTIONS: Please fill-in or circle the appropriate answer to the following list of questions:

\section{GENERAL}

1.1. Country of birth ( If the answer is CANADA, go to 1.3 ) :

1.2. Year immigrated to Canada:

1.3. Ethnicity (circle one):

\begin{tabular}{|l|l|}
\hline 1 & Asian Filipino \\
\hline 4 & Black \\
\hline 7 & North American Indian \\
\hline
\end{tabular}

\begin{tabular}{|l|l|}
\hline 2 & Asian Indian \\
\hline 5 & Caucasian \\
\hline 8 & Other \\
\hline
\end{tabular}

3 Asian Oriental

6 Inuit

9 Unknown

1.4. If Other Ethnicity, Specify:

1.5. Year started on dialysis:

1.6. Are you Diabetic? If the answer is No, go to 1.8 .

1.7. Are you on Insulin?

1.8. Have you ever had active TB? If the answer is No, go to 1.10 .

1.9. If you had TB, was it treated?

1.10. Have you lived with or been in close contact with someone who had active TB?

\section{SYMPTOMS}

Have you experienced any of the following symptoms within the past year?

\begin{tabular}{|l|c||c||c|}
\hline 2.1. Cough (with or without phlegm) for $>3$ weeks: & Yes & No & Unk \\
\hline 2.2. Coughing up blood: & Yes & No & Unk \\
\hline 2.3. Chest pain: & Yes & No & Unk \\
\hline 2.4. Shortness of breath/difficulties breathing: & Yes & No & Unk \\
\hline 2.5. Unexplained fever: & Yes & No & Unk \\
\hline 2.6. Unexplained excessive night sweats: & Yes & No & Unk \\
\hline 2.7. Unexplained weight loss: & Yes & No & Unk \\
\hline 2.8. Unexplained excessive fatigue: & Yes & No & Unk \\
\hline
\end{tabular}




\section{TB Screening Questionnaire}

Page: 2 of 2

\begin{tabular}{|c|c|}
\hline Patient: & Male \\
\hline PHN: & DOB: 31-DEC-99 \\
\hline Addres & \\
\hline & \\
\hline & \\
\hline
\end{tabular}

INSTRUCTIONS: Please fill-in or circle the appropriate answer to the following list of questions:

\section{TB TESTING}

\begin{tabular}{|c|c|c|c|}
\hline 3.1. Have you ever had a TB skin test? If the answer is No, go to 3.4. & Yes & No & Unk \\
\hline 3.2. What was the result? If the answer is No, go to 3.4 . & $>=10 \mathrm{~mm}$ & $<10 \mathrm{~mm}$ & Unk \\
\hline 3.3. Do you have a written proof of TB skin test: & Yes & No & Unk \\
\hline 3.4. Have you ever received BCG vaccination? & Yes & No & Unk \\
\hline 3.5. Have you ever had an abnormal chest x-ray? & Yes & No & Unk \\
\hline
\end{tabular}

\section{CONSIDERING THE LIST OF COUNTRIES/CONTINENTS BELOW:}
a) Africa (any country)
b) Asia (China, Mongolia, Vietnam, Korea, Indonesia, India, Pakistan, Bangladesh, India)
c) Europe (any country of former Soviet Union)
d) Latin America: (Any country)
e) Carribean Islands (Jamaica, Dominican Republic, Haiti, Cuba, Trinidad)
f) Pacific Islands including the Philippines but excluding Hawaii

\begin{tabular}{|c|c|c|c|}
\hline 4.1 Were you born in any of these places? & Yes & No & Unk \\
\hline 4.2 Have you ever stayed/visited in one of these places for $>$ one moth? & Yes & No & Unk \\
\hline $\begin{array}{l}\text { 4.3 Have you ever lived or been in close contact with someone who lived in any of these } \\
\text { places for > one month? }\end{array}$ & Yes & No & Unk \\
\hline
\end{tabular}

\section{COMMENTS}




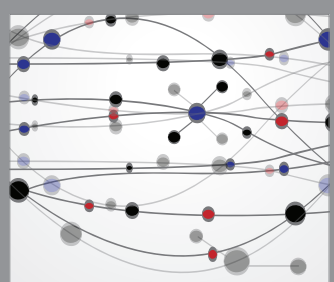

The Scientific World Journal
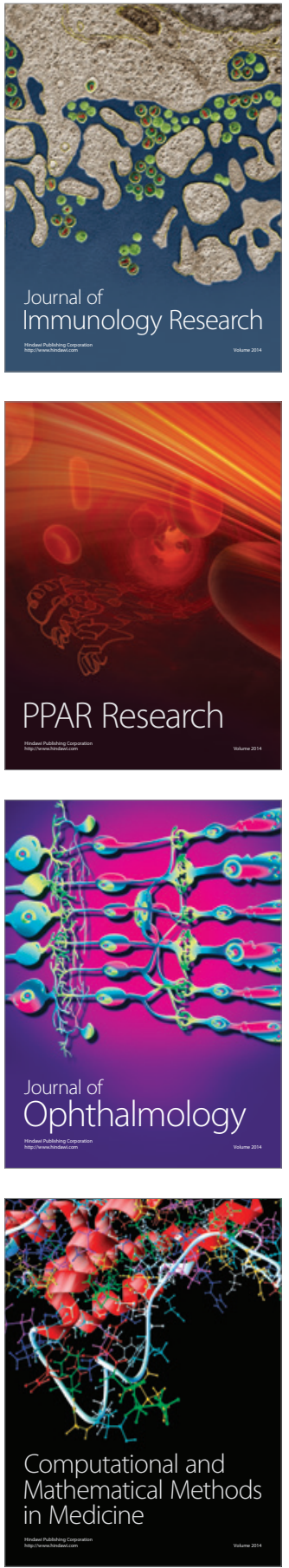

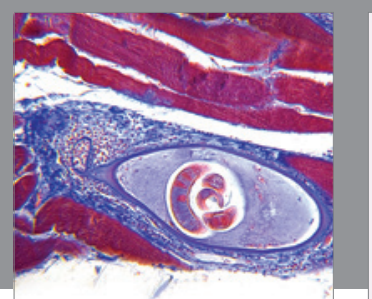

Gastroenterology Research and Practice

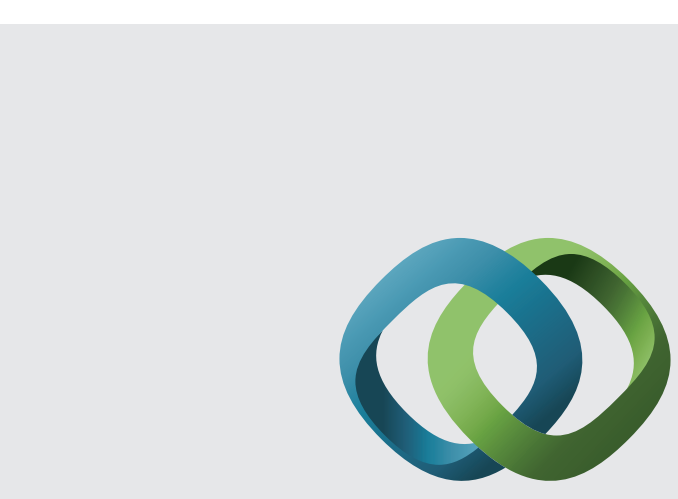

\section{Hindawi}

Submit your manuscripts at

http://www.hindawi.com
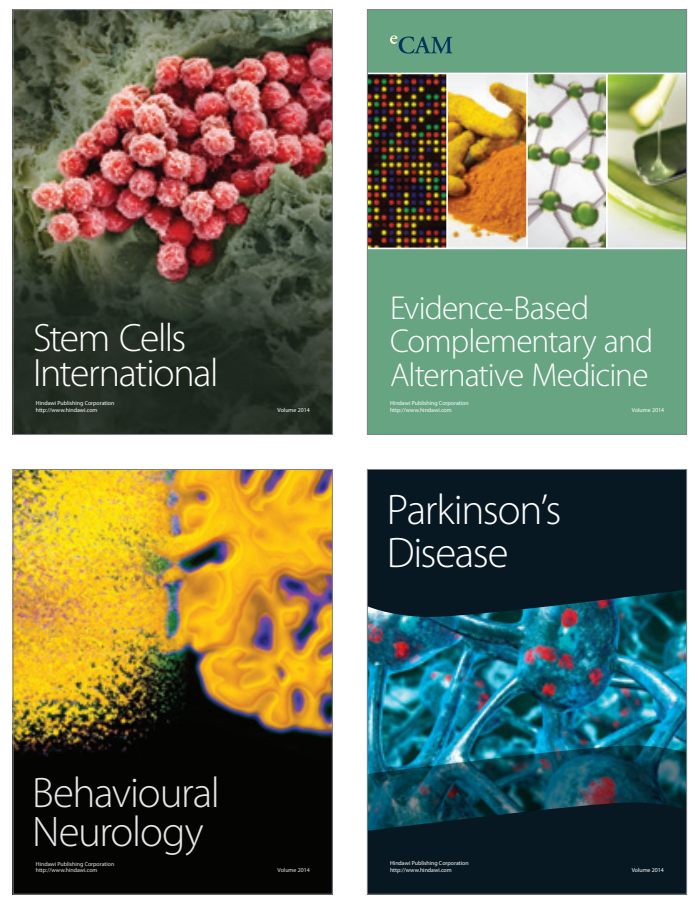
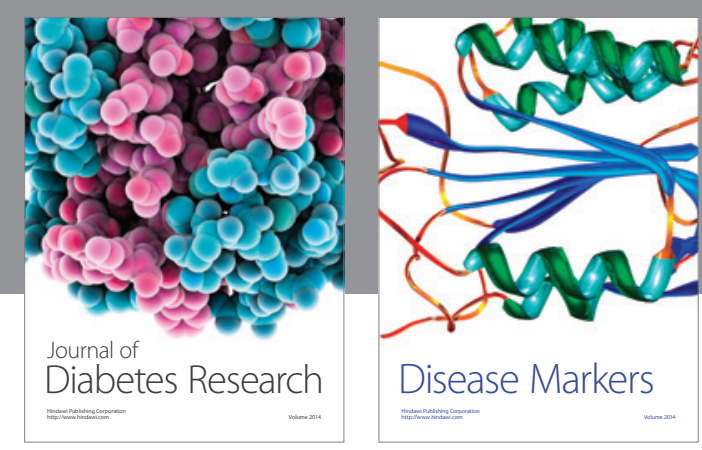

Disease Markers
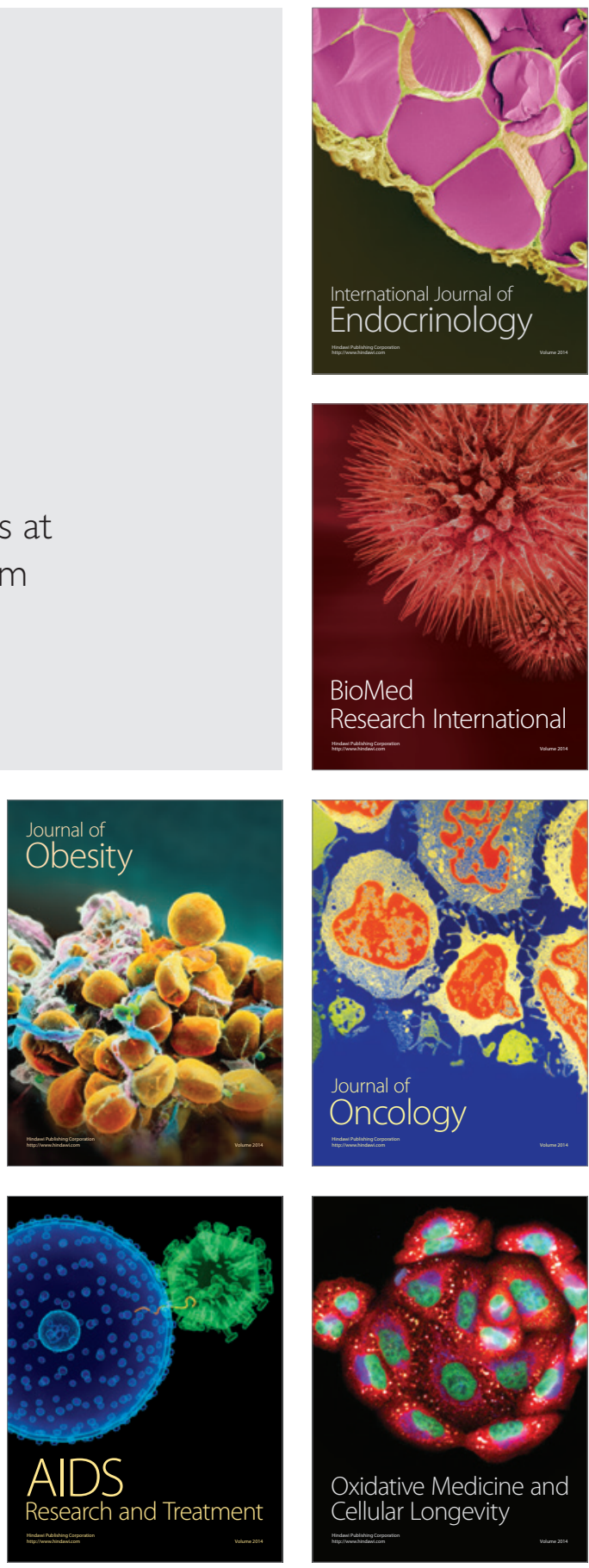